\title{
Report Receiver Received Indicator
}

National Cancer Institute

\section{Source}

National Cancer Institute. Report Receiver Received Indicator. NCI Thesaurus. Code C95391.

An indication as to whether the report was received by the recipient. 